\title{
Evaluating Labour Welfare Legislations and Measures- A Study of Cotton Textile Industry In Punjab
}

\author{
Minakshi Garg", Pardeep Jain \\ Deptt. of Management, SLIET Longowal, Distt Sangrur Punjab \\ *Corresponding Author: minakshi_garg100@rediffmail.com
}

Copyright (C) 2013 Horizon Research Publishing All rights reserved.

\begin{abstract}
Industrial progress depends on satisfied labour force and in this connection the importance of labour welfare measures was accepted long back.. Labour welfare concept is basically based on human values, where each citizen has a right to work in a congenial environment with no hazards to his health on reasonable wages and other terms and conditions of employment. The days are over when labour was considered to be a commodity. When a worker joins industry he has to work in an entire strange atmosphere, creating problems of adjustment. Having a satisfied workforce is very much essential for smooth working of every organization. So this study is conducted to know whether the workers are satisfied with the welfare facilities provided by textile industries in Punjab. This paper has also attempted to study relationship between the sex of the respondents and awareness on welfare measures. The outcome of the study may help the administration and policy makers to differentiate the satisfying factors from dissatisfying and to take effective steps to improve the labour welfare facilities.
\end{abstract}

Keywords Industrialization, Welfare Measures, Satisfaction, Textile industry, Productivity

\section{Introduction}

With the increased industrialization the past practice of workers from villages coming to industries only during off season is diminishing and a large section of industrial workers today entirely depends upon their industrial employment for its livelihood. If care is being taken for their welfare, they will be satisfied and their productivity will increase. Labour welfare measures are an effort towards relieving the industrial workers of their worries and making them happy. Anything done towards the well being of labour force comes under the purview of labour Welfare. "As a matter of fact the whole field of welfare is one in which much can be done to combat the sense of frustration of the industrial worker, to bring about maximum satisfaction, to relieve him of personal and family worries, to afford him a means of sphere in which he can excel all others to keep him to wider conception of life." Welfare work refers to the efforts on the part of employers to improve within the existing industrial system the conditions of employment in their own factories. Any arrangement of working conditions, organization of social and sports club and establishment of funds by firm, which contribute to workers health and safety, comfort, efficiency, economic security, education and recreation is labour welfare measures. It is generally agreed that labour is an underprivileged section of our society. The working environment of any job in a factory imposes some adverse effects on the worker because of the heat, noise, odour, fumes etc. involved in the manufacturing process. There are also occupational hazards and environmental problems inherent and inevitable in the manufacturing process itself, which cannot be removed. As a result protective devices and compensatory benefits have to be provided for labour welfare. Welfare activities influence the sentiments of the workers, when they feel that both the employer and the Government are interested in their welfare and happiness, their tendency to grouse and grumble disappear. This leads to industrial peace which in turn open the way for the development of the country.

\section{Literature Review}

With the dawn of independence, welfare measures for upliftment of labour class were intensified. After independence, the government at a tripartite conference in December 1947 adopted the industrial truce resolution. Several legislations, including the following, were enacted to maintain industrial peace and harmony: Factories Act, 1948, Employees State Insurance Act, 1948 and Minimum Wages Act, 1948. The payment of bonus act was passed in 1965.KumarP.Ashok (2012)in his study on Labour welfare measures in Salem Steel plant examines the significance and objectives of labour welfare and concluded that labour welfare measures helps to promote industrial relations and to reduce the level of absenteeism. 
Shobna Mishra and Dr. Manju Bhagat(2010) in their principles for successful implementation of labour welfare activities stated that labour absenteeism in Indian industries can be reduced to a great extent by provision of good housing, health and family case, Canteen, and provision of welfare activities. The principles for successful implementation of labour welfare activities are nothing but an extension of democratic values in an industrialized society. Report of National Commission on Labour (2002), Government of India, made recommendations in the area of labour welfare measures which includes social security, extending the application of the Provident Fund, gratuity and unemployment insurance etc. A study conducted by Saiyaddin examined the purpose and cost of non-statutory welfare activities for the organizations. Five public and six private sector organizations were selected for the study. The study brought out an important conclusion that the most predominant theme in the minds of organizations when they think of the voluntary welfare measures was not only the output and efficiency but also increasing loyalty and morale. In respect of cost, the study revealed, that the public sector organizations spend more on welfare activities, as compared to private sector. While public sector spends more on transportation and recreation, private sector was found to be spending more on housing according to the study.S.K. Srivastava(2002) studied the impact of labour welfare on job satisfaction in Public \& Private sector in Kanpur city results indicate that welfare activities affect the workers attitude towards management and job satisfaction in both the sectors. If labourers are satisfied their attitudes are also pro and positive attitude pays a great role in the development of an organization.K.K. Jacob(2002) study examines industrial relation in public sector in Kerala. Attention has been paid on exploring the nature and extent of industrial disputes, settlement machinery, working conditions and welfare facilities. He concludes that low wages and bonus, poor working conditions and welfare facilities are the most important factor responsible for industrial disputes.K.L. Bhatia(1986) in his study on the administration of workmen compensation law found that the graver the effect of the accident, the need of help of a trained lower becomes more frequent. There seems to be an immense need of providing free legal aid and advice to the claimants under the Workmen Compensation Act. Also he found that the quantum of compensation fixed by the law did not appear to have been formulated with an eye to the future. There is need for enhancement of compensation in this age of inflation.

\section{Scope of the Study}

The study has been undertaken in the cotton textile industry as it is one of the oldest and most firmly established industries. The concept of labour welfare is dynamic bearing a different interpretation from country to country and from time to time and even in the same country according to value, system, social institutions, degree of industrialization and general level of social and economic development.The scope of labour welfare can be understood by considering both statutory and voluntary welfare measures undertaken by the employers The scope therefore cannot be limited to facilities within or near the undertaking in textile industry in Punjab.

\section{Objectives of the Study}

- To Study the extent of awareness for Labour welfare measures among workers.

- To Study the level of satisfaction among workers for Labour welfare measures.

- To suggest the ways which can fulfill the future needs and aspirations of the workers.

\section{Methodology}

The research design used in this study is descriptive. The study used both primary and secondary data.The primary data collected from respondents through Schedules. Convenience sampling method is adopted to carry out the study. In this connection, 250 workers from textile mills are selected covering almost all the departments on gender ratio of 50:50. In this study the schedule consist of mostly close ended questions with 5-point Likert Scale i.e Highly Satisfied, Satisfied, Average, Dissatisfied and Highly Dissatisfied. The Statistical tools applied for the study is percentages, weighted average mean and Chi Square. The secondary data is collected with the help of various company records, Company manual, Internet, journal, books etc.

\subsection{Data Analysis and Interpretation}

Table 1. Awareness on Statutory Welfare Facilities

\begin{tabular}{|c|c|c|c|}
\hline S.No & $\begin{array}{c}\text { AWARENESSON } \\
\text { STATUTORY } \\
\text { WELFAREFACILITIES }\end{array}$ & $\begin{array}{c}\text { NO. OF } \\
\text { RESPONDENTS }\end{array}$ & PERCENTAGE \\
\hline 1 & Extremely aware & 30 & $2 \%$ \\
\hline 2 & Moderately aware & 150 & $60 \%$ \\
\hline 3 & Somewhat aware & 30 & $12 \%$ \\
\hline 4 & Slightly aware & 20 & $8 \%$ \\
\hline 5 & Not at all aware & 20 & $8 \%$ \\
\hline & Total & 250 & 100 \\
\hline
\end{tabular}

Interpretation: It is witnessed from the table 1 that $60 \%$ of the respondents are moderately aware about welfare facilities with $12 \%$ as somewhat aware. On the other hand $8 \%$ of the respondents stated that no awareness about statutory welfare facilities. From the analysis, it is concluded that most of the respondents having awareness about statutory welfare facilities 
Table 2. Sex And Level Of Awareness On Statutory Welfare Facilities

\begin{tabular}{|c|c|c|c|c|c|c|}
\hline \multirow{2}{*}{ S.No } & \multicolumn{5}{|c|}{ Level Of Awareness } & \multicolumn{2}{c|}{} \\
\cline { 2 - 7 } & Extremely aware & Moderately aware & Somewhat aware & Slightly aware & $\begin{array}{c}\text { Not at all } \\
\text { aware }\end{array}$ & $\begin{array}{c}\text { Total } \\
\text { Male }\end{array}$ \\
\cline { 2 - 7 } & $20(66.7 \%)$ & $83(55.3 \%)$ & $14(46.7 \%)$ & $5(25 \%)$ & $3(15 \%)$ & 125 \\
\hline Female & $10(33.3 \%)$ & $67(44.7 \%)$ & $16(53.3 \%)$ & $15(75 \%)$ & $17(85 \%)$ & 125 \\
\hline & 30 & 150 & 30 & 20 & 20 \\
\hline
\end{tabular}

Interpretation: It is lime lighted from the table II that the percentage of extremely aware of statutory welfare measures in textile industries was the highest (66.7\%) among the Male category of the respondents and the same was the lowest $(33.3 \%)$ among the female category of the respondents. The percentage of moderately aware of statutory welfare measures in textile industries was the highest (55.3\%) among the Male category of the respondents and the same was the lowest $(44.7 \%)$ among the female category of the respondents. Whereas percentage of not at all aware of statutory welfare measures was the highest (85\%) among the female category of the respondents and the same was the lowest $(15 \%)$ among the male category of the respondents.

In order to find the relationship between sex of the respondents and level of awareness on Statutory welfare measures in textile industries, a chi-square test was employed to test the hypothesis and the result of the test is shown in the following table.

Table 3. Sex and Level of Awareness on Statutory Welfare Measures (Chi-Square Test)

\begin{tabular}{|c|c|c|c|}
\hline & Value & $\begin{array}{c}\text { Degree of } \\
\text { Freedom }\end{array}$ & $\begin{array}{c}\text { Table value at 5\% } \\
\text { Significant }\end{array}$ \\
\hline $\begin{array}{c}\text { Pearson } \\
\text { Chisquare }\end{array}$ & 14.34 & 4 & 9.49 \\
\hline
\end{tabular}

Ho : There is no significant relationship between the sex of the respondents and level of awareness on Statutory welfare measures in textile industries.

H1: There is a significant relationship between the sex of the respondents and awareness on statutory welfare measures in textile industries.

Interpretation: It is witnessed from the table III that the calculated chisquarevalue is more than the table value at $5 \%$ significance level. Hence, the null hypothesis Ho is rejected and alternative hypothesis $\mathrm{H} 1$ is accepeted. From the analysis it is concluded that there is significant relationship between the sex of the respondents and level of awareness.

\section{Level of Satisfaction for Welfare Measures}

In the present study 13 provisions are taken into consideration to know the level of satisfaction of the workers on each provision. In order to make the interpretation easier, the mean scores are converted into percentage using the formula. Percentage Score $=($ Mean Score -1$) \times 25$. This is done on the assumption that the mean score of 1 indicates 20 per cent, 2 corresponds to 40 per cent, 3 indicates 60 per cent, 4 corresponds to 80 per cent, and lastly 5 indicates 100 per cent. The per cent score indicates the degree to which a particular dimension exists out of the ideal 100 .

It can be observed from the table IV that the overall mean score of 3.75 i.e. 69 per cent indicates that majority of the respondents are satisfied with the welfare measures provided by the organization. A few are not satisfied with welfare measures provided by the organization. Therefore, it is suggested that the existing welfare measures may be improved further.

Maximum $90 \%, 83 \%, 80 \%, 80 \%, 75 \%$ of the respondents are highly satisfied with Drinking/washing Facilities, working environment (Cleanliness/Lighting/Ventilation), Shelters, Restrooms and lunch rooms and First aid appliances benefits provided by the organization. Minimum of $68 \%, 55 \%$ of the respondents are moderately satisfied with the Crèches and canteen food provided by the organization. Level of satisfaction for Accommodation in Labour Colony and Interest Free Loan for Children education is again average with $60 \%$ and $55 \%$ respectively..Minimum 25\%, of the respondents are highly dissatisfied with the Welfare officers as the representative of the workers rather they are of the opinion that welfare officers do not listen to their problems properly. 
Table 4. Level of SatisfactionfFor Welfare Measures

\begin{tabular}{|c|c|c|c|}
\hline S.No. & Provisions/facilities & Weighted Average mean score & Percentage \\
\hline 1 & Drinking / Washing facilities & 4.6 & $90 \%$ \\
\hline 2 & Facility for storing and drying clothing & 4.0 & $75 \%$ \\
\hline 3 & First aid appliances & 4.2 & $80 \%$ \\
\hline 4 & Canteens & 3.2 & $55 \%$ \\
\hline 5 & Shelters, restrooms and lunch rooms & 4.2 & $80 \%$ \\
\hline 6 & Crèches & 3.7 & $83 \%$ \\
\hline 7 & Working environment & 4.3 & 8.7 \\
\hline 8 & (Cleanliness/Lighting/Ventilation) & 2.0 & $25 \%$ \\
\hline 9 & Welfare officers as the representative of the workers & 4.4 & $85 \%$ \\
\hline 10 & Medical Facilities & 3.7 & $68 \%$ \\
\hline 11 & Retirement Benefits & 3.9 & $73 \%$ \\
\hline 12 & Transport Facility & 3.4 & $60 \%$ \\
\hline 13 & Anterest Free Loan for Children education & 3.2 & $55 \%$ \\
\hline
\end{tabular}

Over all Mean Score $=3.75 \quad$ Over all Percentage $=69$

Table 5. Experience and level of Satisfaction For Welfare Measures

\begin{tabular}{|c|c|c|c|c|c|c|}
\hline \multirow{2}{*}{ Experience/ Satisfaction Level } & \multicolumn{5}{|c|}{ Level Of Satisfaction } & \multicolumn{2}{c|}{$\begin{array}{c}\text { Highly } \\
\text { Dissatisfied }\end{array}$} & Total \\
\cline { 2 - 7 } & Highly Satisfied & Satisfied & Average & Dissatisfied & $8(40 \%)$ & 62 \\
\hline Less than 5 Years & $4(12.9 \%)$ & $15(19.5 \%)$ & $20(27.8 \%)$ & $15(30 \%)$ & $7(35 \%)$ & 63 \\
\hline $5-10$ Years & $5(16.1 \%)$ & $16(20.7 \%)$ & $21(29.2 \%)$ & $14(28 \%)$ & $2(10 \%)$ & 63 \\
\hline $10-15$ Years & $10(32.2 \%)$ & $21(27.3 \%)$ & $19(26.4 \%)$ & $11(22 \%)$ & $3(15 \%)$ & 62 \\
\hline Above 15 Years & $12(38.8 \%)$ & $25(32.5 \%)$ & $12(16.6 \%)$ & $10(20 \%)$ & 20 & 250 \\
\hline
\end{tabular}

Interpretation: The table $\mathrm{V}$ highlights that the percentage of highly satisfied respondents for welfare measures in textile industries was the highest $(38.8 \%)$ who are having experience for more than 15 Years and the same was the lowest $(12.9 \%)$ among there spondents having experience of less than 5 Years. The percentage of average level of satisfaction for welfare measures was highest $(27.8 \%)$ among the respondents having experience of less than 5 Years and the same was the lowest(16.6\%) among the respondents having experience for more than 15 Years. On the other hand the percentage of low level of satisfaction for welfare measures in textile industries was the highest $(40 \%)$ among the respondents having experience of less than 5 Years and the same was the lowest (10\%) among the respondents having experience between 10-15 Years.
So from the above analysis it is inferred that the respondent shaving experience between 10-15 Years and Above 15 Years is highly satisfied with welfare measures when compared with other categories. It is proved with the help of chi-square test that there is a closere lationship between Experience of the respondents and the level of satisfaction for welfare measures In order to find the relationship between the respondents' income and the level of satisfaction for welfare measures in textile industries, a chi-square test is shown in the following table.

Ho: There is no significant relationship between the respondents' Experience and their level of satisfaction for welfare measures in textile industries.

H1: There is a significant relationship between respondents' respondents' Experience and their level of satisfaction for 
welfare measures in textile industries.

Table 6. Experience And Level Of Satisfaction For Welfare Measures (Chi-Square Test)

\begin{tabular}{|c|c|c|c|}
\hline & Value & $\begin{array}{c}\text { Degree of } \\
\text { Freedom }\end{array}$ & $\begin{array}{c}\text { Table value at 5\% } \\
\text { Significant }\end{array}$ \\
\hline $\begin{array}{c}\text { Pearson } \\
\text { Chisquare }\end{array}$ & 23.57 & 12 & 21.03 \\
\hline
\end{tabular}

Interpretation: It is witnessed from the table VI that the calculated chisquarevalue is more than the table value at $5 \%$ significance level. Hence, the null hypothesis Ho is rejected and alternative hypothesis $\mathrm{H} 1$ is accepeted. From the analysis it is concluded that there is significant relationship between the experience of the respondents and level of satisfaction for welfare measures.

\section{Findings and Suggestions}

- It is found that majority of respondents are aware of statutory welfare facilities.

- Female workers are less aware of the statutory welfare facilities so steps should be taken to aware them on the same.It is proved with the help of chi-square test there is a significant relationship between the sex of the respondents and the level of awareness for welfare measures

- Most of the workers are highly benefited with the welfare measures provided by the textile industry. On the whole, majority of the workers are satisfied with the welfare measures provided by the textile industries. Improvements are required in the canteen facilities; so that workers are able to get hygienic and good quality food.

- Betterment is required in the work of welfare officer as most of the workers are of the opinion that they do not pay attention to their problems or grievances.

- Management can think of formulation of a problem solving committee for the better solution of the welfare problems of the workers. This committee can conduct hearings from the workers or they can conduct surprise visits to the different work spot, etc for understanding and by that solving the problems also

- Most of the employees having between 10-15 years of experience and above 15 years of experience are highly satisfied with the safety measures, working conditions, etc.It is proved with the help of chi-square test there is a close relationship between the experience of the respondents and the level of satisfaction for welfare measures.

\section{Conclusion}

The main objective of this paper is to determine the awareness and satisfactory level of welfare facilities in textile industries. This paper has also attempted to study relationship between the sex of the respondents and awareness level and between the experience of the respondents and the level of satisfaction for welfare measures. The outcome of the study may help the organization to differentiate the satisfying factors from dissatisfying ones and to take effective steps to improve the labour welfare facilities which in turn will increase the workers efficiency and productivity.

\section{REFERENCES}

[1] Aggarwal, A.P., Gueraoes and Industrial relations ; N.M.Tripathi, Bombay; 1968.

[2] Ahluwalia G.S., Philosophies of labour welfare; Indian Journal of social work; vol. 14; No. 1; 1953.

[3] Bhatnagar, Deepti., State and Labour welfare in India; Deep and Deep Publications, New Delhi; 1985

[4] Bhatia,K.L., Administration of Workmen's Compensation Law: A socio Legal Study; Deep and Deep Publications, New Delhi ; 1986.

[5] Chopra, V.S., Strategies for healthy Labour Management relations; Haryana Labour Journal; vol.150, no. 3; July Sept.1984.

[6] Damle, D.G., Provident Fund for Workers; Indian Journal of Social Work; Vol.29; No.107; 1976.

[7] Jacob, K.K., (2002), Industrial relations in Public Sector in Kerala. Ph.D. Thesis, University of Kerala

[8] Jain R.C., Path to Industrial peace ; Indian Labour Journal ; Vol. 24; No. 2; 1983.

[9] Kirkaddy ,H.S., Labour problem in India: S. Chand \& Co. Ltd, Delhi ;1981;P.226.

[10] Kumar.P.Ashok., A Study on Labour welfare measures in Salem steel plant;Vol.2. issue:3;March 2012.

[11] Mathur, D.C., Personnel problems and labour welfare; Mittal Publications,New Delhi,1993

[12] Mishra.S.N., Labour and Industrial Laws,Central law Publications,Allahabad;1997.

[13] Misra, K.K. "Labour Welfare in Indian Industries" Meenakshi Prakashan, Meetut,1974.

[14] Monga, M.L., Implementation of labour laws in Haryana; Punjabi University, Patiala, 1980; P. 56.

[15] Moorthy, M.V., Labour Welfare, Indian Journal of Social Work; Vol.11; No. 3; 1950.

[16] Personnel Management and Industrial Relations - Tripathi ; Bombay, 19th edition, reprint 2008

[17] Report of National Commission on Labour, Government of India, 2002

[18] Richardson, J.H., Industrial relations in Great Britian; George Allen and Unwin ;London 1960; P.172.

[19] ShobnaMishra \&Dr. Manju Bhagat2010), Principles for successful implementation of labour welfare activities from police theory to functional theory Retrieved June 10, 2010, from http://www.tesionline.com/intl/indepthjsp 
[20] Sharma, A.M.,Industrial relations, Himalaya Publishing House;New Delhi,2007.

[21] Singh, A.P. and Srivastava , A.K., Occupational Level and Job Satisfaction; Journal of Public relations ; 19 (2) ; May 1975.

[22] Saiyadin S.Mirza, "Voluntary Welfare in India", Lok Udyog October, 1983, PP.29-33.
[23] Vaid , K.N., Labour Welfare in India, Shri Ram Centre for Industrial relations, New Delhi ; 1970.

[24] V. Pylee and A. Simon George, Industrial Relations \& Personnel Management, Vikas Publishing House Pvt. Ltd, New Delhi; 1996, p-78.

[25] Zaheeruddin.,labour Welfare and Employment conditions in India; Deep and Deep Publications, New Delhi ; 1985. 